\title{
3,5-di-iodothyronine stimulates tilapia growth through an alternate isoform of thyroid hormone receptor $\beta 1$
}

\section{Pamela Navarrete-Ramírez, Maricela Luna, Carlos Valverde-R and Aurea Orozco}

Instituto de Neurobiología, Universidad Nacional Autónoma de México (UNAM), Boulevard Juriquilla 3001 Queretaro 76230, Mexico
Correspondence should be addressed to A Orozco

Email

aureao@unam.mx

\begin{abstract}
Recent studies in our laboratory have shown that in some teleosts, 3,5-di-iodothyronine

$\left(T_{2}\right.$ or 3,5-T $\left.T_{2}\right)$ is as bioactive as 3,5,3'-tri-iodothyronine $\left(T_{3}\right)$ and that its effects are in part mediated by a TR $\beta 1$ (THRB) isoform that contains a 9-amino acid insert in its ligand-binding domain (long TR $\beta 1$ (L-TR $\beta 1$ )), whereas $T_{3}$ binds preferentially to a short TR $\beta 1$ (S-TR $\beta 1$ ) isoform that lacks this insert. To further understand the functional relevance of $\mathrm{T}_{2}$ bioactivity and its mechanism of action, we used in vivo and ex vivo (organotypic liver cultures) approaches and analyzed whether $\mathrm{T}_{3}$ and $\mathrm{T}_{2}$ differentially regulate the S-TR $\beta 1$ and L-TR $\beta 1 \mathrm{~s}$ during a physiological demand such as growth. In vivo, $\mathrm{T}_{3}$ and $\mathrm{T}_{2}$ treatment induced body weight gain in tilapia. The expression of L-TR $\beta 1$ and S-TR $\beta 1$ was specifically regulated by $T_{2}$ and $T_{3}$ respectively both in vivo and ex vivo. The TR antagonist 1-850 effectively blocked thyroid hormone-dependent gene expression; however, $T_{3}$ or $T_{2}$ reversed 1-850 effects only on S-TR $\beta 1$ or L-TR $\beta 1$ expression, respectively. Together, our results support the notion that both $T_{3}$ and $T_{2}$ participate in the growth process; however, their effects are mediated by different, specific TR $\beta 1$ isoforms.
\end{abstract}

Key Words

- 3,5- $\mathrm{T}_{2}$

- growth

thyroid hormone receptor

- 1-850

\section{Introduction}

The pleiotropic effects exerted by thyroid hormones (THs) have led to growing interest to identify, besides the amply studied 3,5,3'-tri-iodothyronine $\left(\mathrm{T}_{3}\right)$, other possible bioactive iodothyronines that could explain this diversity of functions. Accordingly, studies from several laboratories have suggested that 3,5 -di-iodothyronine $\left(3,5-\mathrm{T}_{2}\right.$ or $\left.\mathrm{T}_{2}\right)$, a putative product of the outer ring deiodination pathway involved in $\mathrm{T}_{3}$ metabolism, also possesses bioactivity (Goglia 2005). In fact, studies from our laboratory have shown that both $\mathrm{T}_{3}$ and $\mathrm{T}_{2}$ act directly on TH-dependent genes in teleost liver (García-G et al. 2007) and that these genomic actions are mediated by different isoforms of
TR $\beta 1$ (Mendoza et al. 2013). Indeed, results from binding and transactivating assays revealed that the effects of $\mathrm{T}_{2}$ on genomic regulation appear to be mediated by a different isoform of TR $\beta 1$ that is found only in fish and contains a 9-amino acid insert in its ligand-binding domain, and which we have denominated long TR $\beta 1$ (L-TR $\beta 1$ ). By contrast, $\mathrm{T}_{3}$ preferentially binds to and activates the short TR $\beta 1$ (S-TR $\beta 1$; Mendoza et al. 2013). Furthermore, hepatic in vivo expression of L-TR $\beta 1$ is $10^{6}$-fold higher than that of S-TR $\beta 1$, suggesting that, at least in teleosts, the effects of THs are mainly mediated through this isoform. These observations, together with our findings that in vivo, 
$\mathrm{T}_{2}$ and $\mathrm{T}_{3}$ modulate the expression of L-TR $\beta 1$ and S-TR $\beta 1$ respectively, suggest a distinct signaling pathway for each $\mathrm{TH}$ in teleosts and prompted us to propose an extra level in the cascade of $\mathrm{TH}$ signaling for which $\mathrm{T}_{2}$ is specifically made and regulated (Mendoza et al. 2013).

In this study and with the aim of further understanding the functional relevance of $\mathrm{T}_{2}$ bioactivity and its mechanism of action, two approaches were employed. In vivo, we analyzed whether $\mathrm{T}_{3}$ and $\mathrm{T}_{2}$ differentially regulate the S-TR $\beta 1$ and L-TR $\beta 1$ isoforms during a physiological demand such as body growth. Ex vivo, we closely analyzed the action mechanisms of the observed $T_{3}$ and $T_{2}$ effects and explored whether these mechanisms were indeed mediated by a TR $\beta 1$ isoform. Our results support the idea that at least in teleosts, $T_{2}$ is a relevant, physiologically bioactive $\mathrm{TH}$ whose genomic effects are mediated by a distinct TR $\beta 1$ isoform.

\section{Materials and methods}

\section{Animals}

Tilapia juveniles $(\sim 0.8 \pm 0.1 \mathrm{~g})$ were kindly provided by SAGARPA (Querétaro, Mexico). Fish were kept in 101 tanks containing constantly aerated fresh water at a temperature of $25^{\circ} \mathrm{C}$ and maintained on a $12 \mathrm{~h}$ light: $12 \mathrm{~h}$ darkness cycle. The fish were fed twice a day ( $\sim 40 \mathrm{mg} /$ fish per day) with a commercial diet (Sera Marin, Sera, Germany). All animal experimentation (handling and killing) was conducted in accordance with accepted procedures regarding handling and killing of the animals, as reviewed and approved by the Animal Welfare Committee of our Institute.

\section{In vivo experimental design}

In all cases, initial fish body weight was recorded before treatments. Experimental groups consisted of ten individuals per group, and all experiments were performed in duplicate tanks (total of 20 fish per experimental group). Fish were treated by immersion in a $1 \mathrm{nM}$ solution of one of the following TH (Sigma): $\mathrm{T}_{3}, \mathrm{~T}_{2}$, or the inactive isomer $\mathrm{rT}_{3}$. A negative control group was treated with $4.5 \mathrm{mM}$ methimazole (MMI; Sigma). The administration protocol was previously described (Navarrete-Ramírez et al. 2011) and consisted of adding a fresh batch of MMI or $\mathrm{TH}$ previously solubilized in $0.05 \mathrm{M} \mathrm{NaOH}$ to the corresponding tank in the morning (0900 h). The treatment was terminated after $8 \mathrm{~h}$ by changing the culture water, and this drug administration protocol was repeated three times per week. Treatments were administered for 1 month, after which the fish were weighed and decapitated, and their livers were rapidly removed. In all cases, livers from each experimental group were divided into two and used for RNA and $\mathrm{TH}$ extraction (see below).

\section{Ex vivo experimental design}

Organotypic cultures of tilapia liver For each experiment, individual juvenile tilapia livers were dissected and placed in ice-cold 50\% Hank's Balanced Salt Solution (Gibco), which contained 50\% Minimum Eagle's Medium (MEM, Gibco), $10 \mathrm{mM}$ HEPES, and $8 \mathrm{mM}$ glucose $(\mathrm{pH}$ 7.2). Livers were sectioned at $400 \mu \mathrm{m}$ thickness on a Mcllwain tissue chopper (about 18 slices per liver). For each treatment, at least five tilapia livers were sliced and randomly placed onto inserts of semiporous membranes made of Biopore CM hydrophilized PTFE, pore size $0.4 \mu \mathrm{m}$ (six slices per membrane (Millipore, Herts, $\mathrm{UK})$ ), and maintained in an incubator at $18{ }^{\circ} \mathrm{C}$ in $5 \% \mathrm{CO}_{2}$. The culture medium consisted of 50\% MEM, $10 \mathrm{mM}$ HEPES, and 35\% Hank's Balanced Salt Solution supplemented with $10 \%$ horse serum (Gibco), $8 \mathrm{mM}$ glucose, and $5 \%$ penicillin-streptomycin (Gibco).

Treatments After $48 \mathrm{~h}$ of stabilization, the medium of each well $(1.1 \mathrm{ml} /$ well) was removed and replaced by the appropriate amount of fresh medium, which contained the different drug treatments: $\mathrm{T}_{3}$ or $\mathrm{T}_{2}$ at concentrations of 0.1 , 1,10 , and $100 \mathrm{nM}$ previously solubilized in $\mathrm{NaOH}$ or the TR antagonist 1-850 (Schapira et al. 2003; Calbiochem, Darmstadt, Germany) previously solubilized in DMSO at concentrations of $0.1,1,10$, and $20 \mu \mathrm{M}$ alone or combined with $100 \mathrm{nM} \mathrm{T}_{3}$ or $\mathrm{T}_{2}$. In all cases, after a 24-h incubation, slices from each plate were removed and pooled for mRNA extraction and quantification. All experiments were performed independently at least twice in duplicate.

\section{Quantification of intrahepatic $T_{3}$}

TH extraction Liver segments from five individual fish per experimental groups were pooled ( $\sim 50 \mathrm{mg}$ tissue/ pool) and homogenized in ten volumes of methanol: ammonium hydroxide (99:1) solution, as described previously (Garcia-G et al. 2004). The homogenates were centrifuged for $10 \mathrm{~min}$ at $700 \mathrm{~g}$. The supernatants were collected, evaporated in a speed vacuum, and suspended 1:5 (initial $\mathrm{w} / \mathrm{v}$ ) in assay buffer Tris- $\mathrm{HCl}$ (0.05 M; pH 8.6).

Published by Bioscientifica Ltd. 
T $_{3}$ RIA Intrahepatic $\mathrm{T}_{3}$ content was measured by RIA as described previously (Orozco et al. 1992). The inter- and intra-assay coefficients of variation were 9.5 and $6.6 \%$ respectively. The incubation mixture contained assay buffer and a working dilution (1:8000) of anti- $\mathrm{T}_{3}$ serum (Sigma), standard (standard curve, 7.8-1000 pg/dl), the radioactive solution $\left(10 \mathrm{pg} / 100 \mu \mathrm{l}\right.$ of the labeled $\mathrm{T}_{3}$ plus $10 \mathrm{mg} / 10 \mathrm{ml}$ 8-anilino-1-naphthalene sulfonic acid (Sigma)), and $50 \mu \mathrm{l}$ of the experimental sample. Free and antibody-bound radioactive $\mathrm{T}_{3}$ were separated using $0.5 \%$ activated charcoal/dextran solution (Sigma).

\section{Measurement of mRNA expression}

In all cases, mRNA was quantified by real-time PCR as described previously (Mendoza et al. 2013). Briefly, total RNA was extracted from juvenile tilapia liver (TRIzol, Invitrogen), and RT (M-MLV, Promega) from $2 \mu \mathrm{g}$ of total hepatic RNA was performed using oligo(dT) primer (final volume of $25 \mu \mathrm{l}$ ). $\beta$-actin was used as an internal standard in reactions that contained $1 \mu \mathrm{l}$ of the RT reaction, $6 \mu \mathrm{l}$ Maxima SYBR Green/ROX qPCR Master Mix (Fermentas, Waltham, MA, USA), and $500 \mathrm{nM}$ forward and reverse primers in a final volume of $12 \mu \mathrm{l}$. Oligonucleotides and PCR protocols used for all gene amplification are specified in Table 1 . In all cases, the standard curve ranged from $10^{1}$ to $10^{9}$ molecules/ $\mu \mathrm{l}$, and a Light Cycler instrument was used for detection and data analyses according to the manufacturer's instructions (Roche Molecular Biochemicals). The mRNA concentration was expressed as molecules per microgram of total mRNA used in the RT reaction $(2 \mu \mathrm{g})$ and obtained by comparison with the standard curve, normalized to the concentration of $\beta$-actin in each experimental sample. Identical PCRs from the RNA samples before the RT reaction yielded no detectable products.

\section{Statistical analysis}

Results obtained in all experiments were analyzed using a one-way ANOVA coupled with the Tukey's multiplecomparison test (control vs treatments). Differences were considered statistically significant at $P$ values of $\leq 0.05$.

\section{Results}

\section{In vivo experiments}

Validation of iodothyronine treatment An initial aim of this study was to test $\mathrm{T}_{2}$ bioactivity. To this end, effects of $\mathrm{T}_{2}$ on body growth were measured as weight gain. As this is a long-term treatment, we designed an administration protocol that consisted in exposing the fish to very low doses of $\mathrm{TH}$ ( $1 \mathrm{nM}$ in water culture) and limited the exposure to $8 \mathrm{~h} /$ day, 3 days/week for 1 month. This hormone concentration is at least ten times lower than that employed in other studies (Lam 1980, Nacario 1983, Lam \& Sharma 1985, Reddy \& Lam 1992, De Jesus et al. 1998, Lam et al. 2005). Furthermore, the administration protocol had a positive effect on fish growth and no negative effects on fish survival, while it induced a burst in growth of $\sim 30 \%$ in both $\mathrm{T}_{3}$ - and $\mathrm{T}_{2}$-treated fish (Table 2). Most importantly, the low TH concentrations used did not alter the thyroidal homeostasis of the fish, as judged by the intrahepatic $\mathrm{T}_{3}$ levels, which were similar to those recently reported for intramuscular zebrafish $\mathrm{T}_{3}$ and $\mathrm{T}_{2}(1.8 \pm 0.2$ and $2.8 \pm 0.4 \mathrm{ng} / \mathrm{g}$ respectively; Little et al. 2013). Indeed, despite the fact that intrahepatic $T_{3}$ concentrations remained within the euthyroid range in all tilapia treated with the different THs, only fish treated with $1 \mathrm{nM} \mathrm{T}_{3}$ or $\mathrm{T}_{2}$ presented a four fold body weight gain compared with the control group $(P<0.001 ;$ Fig. 1$)$.

Table 1 Oligonucleotide sequences and real-time PCR protocols used to amplify the different genes. In all cases, an initial 10-min denaturing step was included

\begin{tabular}{|c|c|c|c|}
\hline Gene & Amplicon (bp) & Forward primer & Reverse primer \\
\hline$\beta$-actin & 170 & ACT TCG AGC AGG AGA TGG & GGT GGT TTC GTG GAT TCC \\
\hline IGF1 & 217 & $\begin{array}{l}\text { AAC CTT GGG TGC TCT } \\
\text { TGG CAT G }\end{array}$ & $\begin{array}{l}\text { GTC TGT GGA GAG CGA } \\
\text { GGC TTT }\end{array}$ \\
\hline L-TR $\beta 1$ & 232 & $\begin{array}{l}\text { GTG AAG GAA GCT AAG } \\
\text { CCT GA }\end{array}$ & $\begin{array}{l}\text { CAC AAG GCA GCT CAC } \\
\text { AGA AC }\end{array}$ \\
\hline S-TR $\beta 1$ & 135 & GCG GAA ATT CCT GCC TGA G & $\begin{array}{l}\text { GCA GCT CAC AGA ACA } \\
\text { TGG GC }\end{array}$ \\
\hline D2 & 249 & GAA ACT TGG CTG TGA GGC & CTC GTC GAT GTA GAC CAG \\
\hline
\end{tabular}

\begin{tabular}{|c|c|}
\hline Real-time PCR protocol & $\boldsymbol{R}$ \\
\hline $\begin{array}{l}3 \mathrm{~s} \text { at } 95^{\circ} \mathrm{C} ; 7 \mathrm{~s} \text { at } 52^{\circ} \mathrm{C} \text {; and } \\
8 \mathrm{~s} \text { at } 72^{\circ} \mathrm{C} \text { for } 45 \text { cycles }\end{array}$ & 1.96 \\
\hline $\begin{array}{c}3 \mathrm{~s} \text { at } 95^{\circ} \mathrm{C} ; 8 \mathrm{~s} \text { at } 56^{\circ} \mathrm{C} \text {; and } \\
9 \mathrm{~s} \text { at } 72^{\circ} \mathrm{C} \text { for } 45 \text { cycles }\end{array}$ & 1.80 \\
\hline $\begin{array}{c}3 \mathrm{~s} \text { at } 95^{\circ} \mathrm{C} ; 10 \mathrm{~s} \text { at } 52^{\circ} \mathrm{C} \text {; and } \\
10 \mathrm{~s} \text { at } 72{ }^{\circ} \mathrm{C} \text { for } 55 \text { cycles }\end{array}$ & 1.96 \\
\hline $\begin{array}{c}2 \mathrm{~s} \text { at } 95^{\circ} \mathrm{C} ; 8 \mathrm{~s} \text { at } 52^{\circ} \mathrm{C} \text {; and } \\
7 \mathrm{~s} \text { at } 72^{\circ} \mathrm{C} \text { for } 45 \text { cycles }\end{array}$ & 2.01 \\
\hline $\begin{array}{c}2 \mathrm{~s} \text { at } 95^{\circ} \mathrm{C} ; 7 \mathrm{~s} \text { at } 58^{\circ} \mathrm{C} \text {; and } \\
10 \mathrm{~s} \text { at } 72^{\circ} \mathrm{C} \text { for } 55 \text { cycles }\end{array}$ & 2.08 \\
\hline
\end{tabular}

$R$, amplification efficiency for the standard curve.

http://jme.endocrinology-journals.org DOI: 10.1530/JME-13-0145
C 2014 Society for Endocrinology Printed in Great Britain
Published by Bioscientifica Ltd 
Table 2 Juvenile tilapia weights before and after a 30-day treatment with the different thyroid hormones $(1 \mathrm{nM})$ or methimazole $(4.5 \mathrm{mM})$. Values are means \pm s.E.M. $(n=20)$

\begin{tabular}{|c|c|c|}
\hline Treatment & Initial weight (g) & Final weight $(g)$ \\
\hline Control & $0.885 \pm 0.015$ & $1.019 \pm 0.625$ \\
\hline$r T_{3}$ & $0.916 \pm 0.006$ & $1.041 \pm 0.710$ \\
\hline $\mathrm{T}_{3}$ & $0.853 \pm 0.0375$ & $1.690 \pm 0.880$ \\
\hline $\mathrm{T}_{2}$ & $0.810 \pm 0.010$ & $1.628 \pm 0.865$ \\
\hline MMI & $0.788 \pm 0.0025$ & $0.865 \pm 0.350$ \\
\hline
\end{tabular}

By contrast, weight gain of $\mathrm{rT}_{3}$-treated fish was similar to that observed in euthyroid tilapia, while those exposed to MMI exhibited the lowest intrahepatic concentration of $\mathrm{T}_{3}$ $(P<0.001)$ and the lowest rate of weight gain (Fig. 1).

\section{Regulation of TR $\beta 1$ isoforms by $T_{3}$ and $T_{2}$}

Given that $T_{3}$ and $T_{2}$ treatment induced growth to a similar extent, we then analyzed whether their effects were differentially mediated by the S-TR $\beta 1$ and L-TR $\beta 1$ isoforms. To this end, hepatic expression of the mRNA for these two TR $\beta 1$ s was quantified. As shown in Fig. 2, hepatic expression of the short isoform of TR $\beta 1$ was higher only in fish exposed to $\mathrm{T}_{3}$. By contrast, expression of the L-TR $\beta 1$ isoform was upregulated only in the liver of tilapia treated with $1 \mathrm{nM} \mathrm{T}_{2}$; no upregulation was observed in the group of $\mathrm{rT}_{3}$-treated fish (Fig. 2). mRNA levels of both TR $\beta 1$ isoforms in MMI-treated fish were significantly decreased compared with the control group. The fact that $\mathrm{T}_{2}$ and $\mathrm{T}_{3}$ exclusively upregulate the expression of the long and short isoforms of TR $\beta 1$ respectively suggests that the effects of these two THs are mediated by two distinct isoforms of TR $\beta 1$.

\section{Effect of $T_{3}$ and $T_{2}$ on hepatic IGF1 and D2 expression}

In order to analyze whether the differential observed effects of $\mathrm{T}_{3}$ and $\mathrm{T}_{2}$ on the expression of L-TR $\beta 1$ and S-TR $\beta 1$ s were specific, hepatic expression of two other TH-regulated genes was quantified. IGF1 (igf1) and D2 (d2) genes were chosen as they are positively and negatively regulated by THs respectively (Schmid et al. 2003). As depicted in Fig. 2, treatment with $\mathrm{T}_{3}$ and $\mathrm{T}_{2}$ equivalently enhanced hepatic expression of IGF1 and blocked that of D2; thus, $\mathrm{T}_{3}$ and $\mathrm{T}_{2}$ do not differ in how they regulate the expression of these two genes. $\mathrm{rT}_{3}$-treated fish showed euthyroid levels of hepatic expression of IGF1 and D2, while those in MMI-treated fish were significantly decreased (IGF1) and increased (D2).

\section{Ex vivo experiments}

\section{Regulation of gene expression by $T_{3}$ and $T_{2}$}

Organotypic liver cultures responded to $\mathrm{TH}$ treatment. Expression of mRNA for IGF1 and D2 was up- and downregulated by $T_{3}$ and $T_{2}$ treatments respectively (Fig. 3). This pattern of regulation was similar to that observed in the in vivo experiments, validating the use of organotypic liver cultures to study the regulation of TH-regulated genes. We then analyzed whether cultures treated with $\mathrm{T}_{3}$ or $\mathrm{T}_{2}$ showed differential regulation of the two TR $\beta 1$ isoforms. Interestingly, the pattern of TR $\beta 1$ regulation by $\mathrm{T}_{3}$ and $\mathrm{T}_{2}$ was inverted when compared with the in vivo studies. Indeed, the expression of the short isoform of TR $\beta 1$ was lower only in fish exposed to $T_{3}$, whereas the expression of the L-TR $\beta 1$ isoform was downregulated only in the liver cultures treated with $\mathrm{T}_{2}$ (Fig. 4). Furthermore, in agreement with the reported affinity of the tilapia TR $\beta 1$ isoforms for their corresponding ligands (Mendoza et al. 2013), $\mathrm{T}_{2}$ treatment did not influence
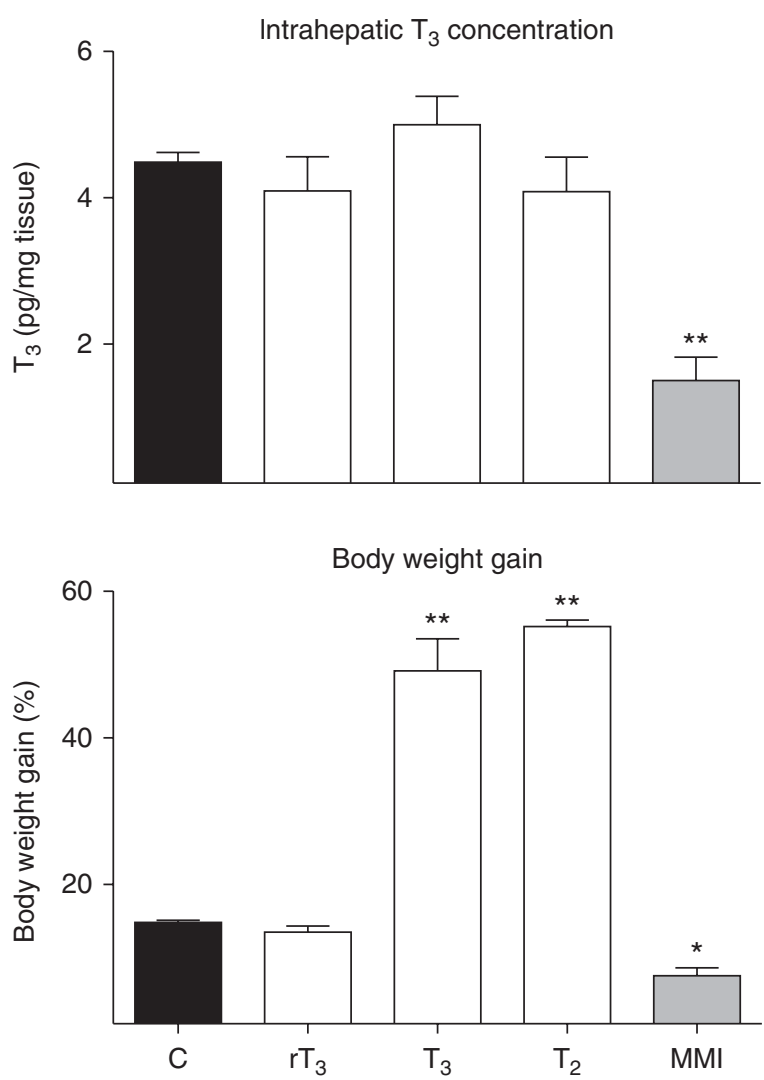

Figure 1

(Top panel) Intrahepatic $T_{3}$ concentrations. (Bottom panel) Body weight gain. Tilapia were treated for 30 days with $1 \mathrm{nM} \mathrm{T}_{3}, \mathrm{~T}_{2}$, or $\mathrm{rT}_{3}$. A negative control group was treated with $4.5 \mathrm{mM} \mathrm{MMI}$. Values are means \pm s.E.M. $(n=20)$. Significance is indicated $(* P<0.05$ and $* * P<0.001)$.

Published by Bioscientifica Ltd 

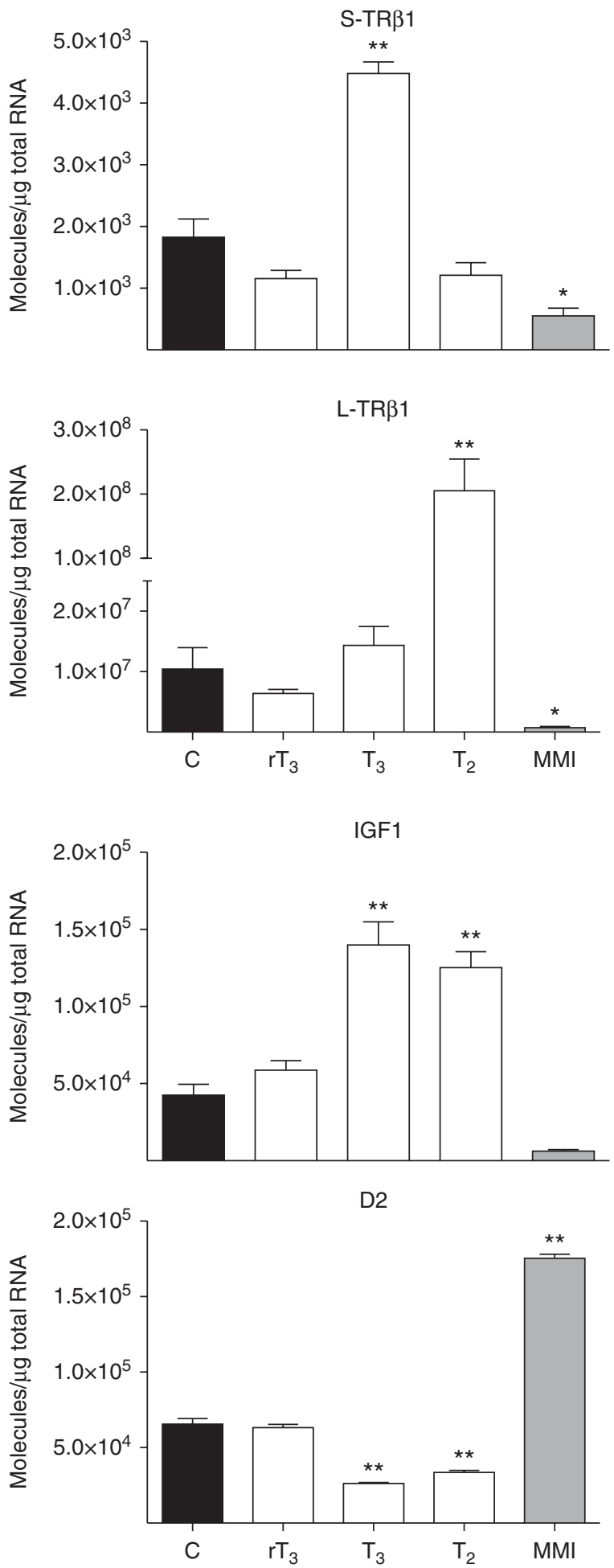

Figure 2

Hepatic mRNA expression of short TR $\beta 1$, long TR $\beta 1$, IGF1, and D2. Tilapia were exposed to $1 \mathrm{nM} \mathrm{T}_{3}, \mathrm{~T}_{2}$, or $\mathrm{rT}_{3}$ for 30 days. The negative control was exposed to $4.5 \mathrm{mM}$ MMI. Values are means \pm S.E.M. Significance is indicated $(* P<0.05$ and $* * P<0.001)$.
๑ 2014 Society for Endocrinology Printed in Great Britain
S-TR $\beta 1$ expression even at the highest concentrations tested $(100 \mathrm{nM})$, although this concentration of $\mathrm{T}_{3}$ did downregulate L-TR $\beta 1$. The fact that $\mathrm{T}_{2}$ and $\mathrm{T}_{3}$ specifically downregulate the expression of the long and short isoforms of TR $\beta 1$ respectively further supports the notion that the effects of these two THs are mediated by two distinct isoforms of TR $\beta 1$ (Fig. 4).

Effects of the TR antagonist 1-850 upon gene expression As shown in Fig. 3, and consistent with their regulation by THs, $1-850$ effectively blocked IGF1 expression while it increased that of D2, further supporting the idea that both hormones act through a TR pathway. Furthermore, the co-treatment with $100 \mathrm{nM} \mathrm{T}_{3}$ or $\mathrm{T}_{2}$ reversed the effects of the TR antagonist 1-850, an effect that was blunted at 10 and $20 \mu \mathrm{M}$ antagonist, probably because $1-850$ has a 1000-fold lower affinity than $\mathrm{T}_{3}$ for the receptor (Schapira et al. 2003). The expression of the long and short isoforms of TR $\beta 1$ was not affected by 1-850 treatment; however, $\mathrm{T}_{3}$ and $\mathrm{T}_{2}$ co-administration downregulated S-TR $\beta 1$ and L-TR $\beta 1$ respectively only at low $(0.1$ and $1 \mu \mathrm{M})$ concentrations of 1-850 (Fig. 4).

\section{Discussion}

Our previous studies support the notion that $\mathrm{T}_{2}$ bioactivity in fish is mediated by the L-TR $\beta 1$ isoform, whereas $\mathrm{T}_{3}$ acts by binding to the S-TR $\beta 1$ isoform (Mendoza et al. 2013). As we used either mammalian GH3 cells, or fish acutely treated with $T_{3}$ and $T_{2}$ in those experiments, the observed TR $\beta 1$ isoform specificity for a given ligand could not be functionally corroborated. Thus, one of the goals of this study was to analyze whether $T_{2}$, like $T_{3}$, could regulate a physiological demand such as growth and whether this regulation was mediated by the L-TR $\beta 1$ isoform. We here show for the first time that treatment with $\mathrm{T}_{2}$ effectively stimulates growth in tilapia fingerlings in the same manner as observed for $\mathrm{T}_{3}$. Therefore, and although the effects of THs on growth have been solely attributed to $T_{3}$ (Power et al. 2001), our present results clearly show that $\mathrm{T}_{2}$ is also a physiologically active player in this process, at least in tilapia, validating fish growth as a useful marker to analyze the possible differential regulation of the TR $\beta 1$ isoforms that mediate $\mathrm{T}_{3}$ and $\mathrm{T}_{2}$ effects.

Results from both in vivo and ex vivo $\mathrm{T}_{3}$ or $\mathrm{T}_{2}$ treatments revealed an equivalent enhancement of IGF1 and blockade of D2 liver expression, showing that $\mathrm{T}_{3}$ and $\mathrm{T}_{2}$ do not differ in how they regulate the transcription

Published by Bioscientifica Ltd 

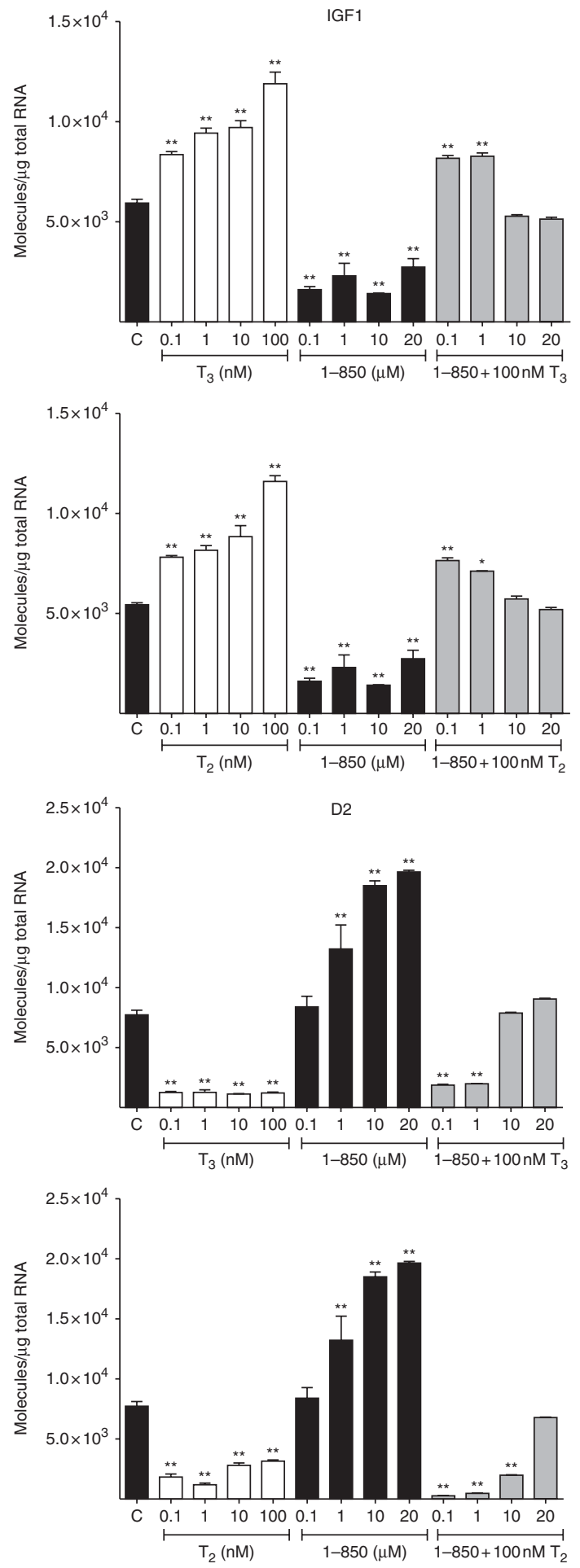

Figure 3

mRNA expression from organotypic liver cultures of IGF1 and D2. Tilapia organotypic liver cultures were treated for $24 \mathrm{~h}$ with $0.1-100 \mathrm{nM} \mathrm{T}_{3}$ (top panel) or $\mathrm{T}_{2}$ (bottom panel), or with $0.1-20 \mu \mathrm{M}$ of $1-850$ without or with $100 \mathrm{nM} \mathrm{T}_{3}$ (top panel) or $\mathrm{T}_{2}$ (bottom panel, $n=6$ slices per experimental group). Values are means \pm s.E.M. of three independent experiments. Significance is indicated $(* P<0.01$ and $* * P<0.001)$. Printed in Great Britain of these two genes. By contrast, results regarding the regulation of the TR $\beta 1$ gene by $T_{3}$ and $T_{2}$ under the two experimental approaches were different. In previous studies, in which tilapia were acutely treated with either $\mathrm{T}_{3}$ or $\mathrm{T}_{2}$, the classical downregulatory response of the liver S-TR $\beta 1$ and L-TR $\beta 1$ mRNAs respectively was observed (Mendoza et al. 2013); this effect was also seen here in the organotypic liver cultures (Fig. 4) and was previously reported for the TR $\beta 1$ gene in other vertebrates treated with $\mathrm{T}_{3}$ (Sadow et al. 2003). Interestingly, however, in the present long-term (1 month) in vivo studies, the expression of mRNAs for both the L-TR $\beta 1$ and S-TR $\beta 1$ was upregulated by $T_{2}$ and $T_{3}$ treatment respectively (Fig. 2). This regulatory pattern resembles that of tadpoles (Sachs et al. 2000, Tata 2000) and flatfish (Yamano \& Miwa 1998, Marchand et al. 2004, Galay-Burgos et al. 2008), in which a pre-metamorphic rise in circulating THs is followed by an increase in the expression of TR $\beta 1$. The auto-induction of TR and other nuclear receptors is linked to developmental actions and seems to be a prerequisite for a sequential activation of target genes involved in a specific biological action (Tata 2002). As there were no age or environmental distinctions between tilapia in previous study (Mendoza et al. 2013) and this study, it is reasonable to suggest that the observed differences in TR $\beta 1$ regulation are mainly due to the administration protocols. Thus, we hypothesize that the intermittent administration protocol used in the present set of experiments partially mimics the pulsatile physiological stimulus of THs and increases the number of receptors, which in turn activate growth-related target genes to stimulate body growth, an event that, like metamorphosis, involves proliferative effects.

We had previously shown that MMI treatment induced the classic upregulation of both hepatic TR $\beta 1$ isoforms in juvenile tilapia (Mendoza et al. 2013). Surprisingly, the partial blockade of TH synthesis which results from the intermittent MMI administration protocol elicited the opposite regulatory effect, despite the fact that intrahepatic $\mathrm{T}_{3}$ concentrations were below euthyroid levels in both experiments. Interestingly, others have reported a $\mathrm{TR} \beta$, but not $\mathrm{TR} \alpha$, downregulation after up to 15 days of exposure to the goitrogen thiourea $(400 \mu \mathrm{M})$ in metamorphosing Solea senegalensis larvae (Manchado et al. 2009). The fact that both THs and MMI intermittent treatments regulated the TR $\beta$ gene in a manner similar to that observed in metamorphosing fish or amphibian is intriguing, especially as none of the other studied genes elicited such a regulatory response. The underlying mechanisms for this opposite regulation

Published by Bioscientifica Ltd 

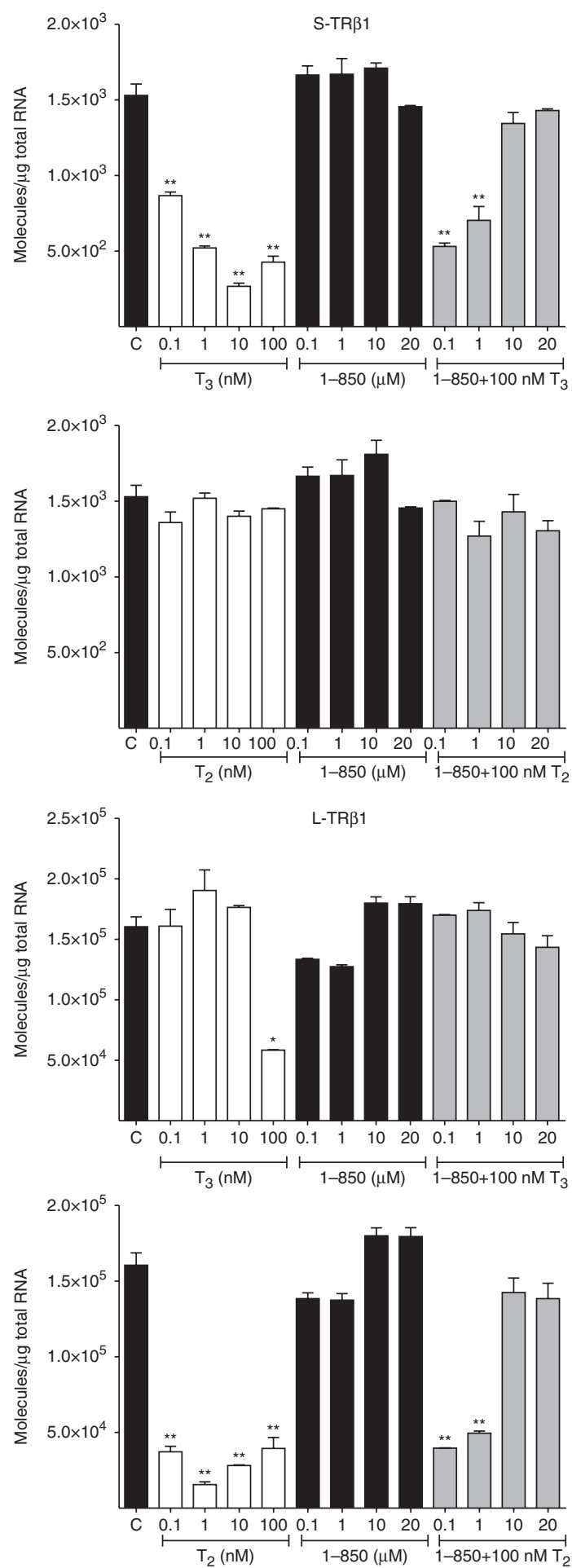

\section{Figure 4}

mRNA expression from organotypic liver cultures of short TR $\beta 1$ and long TR $\beta 1$. Organotypic tilapia liver cultures were treated for $24 \mathrm{~h}$ with 0.1-100 $\mathrm{nM} \mathrm{T}_{3}$ (top panel) or $\mathrm{T}_{2}$ (bottom panel) or with 0.1-20 $\mu \mathrm{M}, 1-850$ without or with $100 \mathrm{nM} \mathrm{T}_{3}$ (top panel) or $\mathrm{T}_{2}$ (bottom panels; $n=6$ slices per experimental group). Values are means \pm s.E.M. of two independent experiments. Significance is indicated $(* P<0.05$ and $* * P<0.001)$. are not known, and further studies would be needed to clarify this issue.

To further support the notion that the actions of $\mathrm{T}_{2}$ upon body weight gain were indeed mediated by the L-TR $\beta 1$ isoform, we treated organotypic liver cultures with the TR antagonist 1-850. This antagonist has been reported to bind with high affinity to both $\operatorname{TR} \alpha$ and $\operatorname{TR} \beta$ in mammalian systems (Schapira et al. 2003). In these studies, 1-850 treatment effectively blocked transcription of a positively regulated gene (IGF1); however, it either enhanced (D2) or had no effect (TR $\beta 1$ s) on transcription of negatively regulated genes. A similar lack of effect on TR $\beta 1$ expression by the TH antagonist NH3 had previously been observed in Xenopus TR $\beta$ A (Opitz et al. 2006). However, the different response patterns of the two negatively regulated genes are intriguing. Several factors may contribute to this response, i.e. unliganded TRs have ligand-independent actions; thus, unligandedor 1-850-liganded TRs may adopt altered conformations, which could change coregulator recruitment and specific gene expression independently of the effects on $\mathrm{TH}$ binding (Shah et al. 2008). Nonetheless, in all cases, the effects of 1-850 were blunted after treatment with $\mathrm{T}_{3}$ or $\mathrm{T}_{2}$. Importantly, $\mathrm{T}_{3}$ reversed the effects of $1-850$ only upon the expression of the S-TR $\beta 1$ isoform and $T_{2}$ had similar effects only upon that of the L-TR $\beta 1$ isoform, further demonstrating that this L-TR $\beta 1$ isoform selectively mediates $\mathrm{T}_{2}$ actions.

Aside from its well-described extranuclear effects upon metabolism in mammals (Goglia 2005), the physiological relevance of $\mathrm{T}_{2}$ has been unnoticed until recently, and $\mathrm{T}_{3}$ has been accepted as the foremost $\mathrm{TH}$ capable of genomic action. A major finding in this study consists in the demonstration that, through interacting with a specific and distinct TR $\beta 1$ isoform, $\mathrm{T}_{2}$ effectively triggers an outburst of body growth in tilapia fingerlings, with an efficiency comparable to that of $\mathrm{T}_{3}$. These results confirm and extend previous reports from our laboratory and others suggesting that $\mathrm{T}_{2}$ is also an important transcriptional regulator, at least in teleosts (García-G et al. 2004, 2007, Little et al. 2013, Mendoza et al. 2013). The lack of available data on circulating or intratissular $\mathrm{T}_{2}$ concentrations has masked the importance of this $\mathrm{TH}$. However, very recent studies have shown that zebrafish intramuscular $\mathrm{T}_{2}$ concentrations closely resemble those of $\mathrm{T}_{3}$ (Little et al. 2013). These data together with our previous findings that $\mathrm{T}_{2}$ preferentially binds to and activates the L-TR $\beta 1$, an isoform that is expressed in vivo at $10^{6}$-fold higher levels than S-TR $\beta 1$, support the notion that, at least in teleosts, $\mathrm{T}_{2}$ is physiologically relevant

Published by Bioscientifica Ltd 
(Mendoza et al. 2013). As previously described for $T_{3}$ and the THRA gene in HepG2 cells (Timmer et al. 2003), the present results are also consistent with the notion that $T_{3}$ and $\mathrm{T}_{2}$ can differentially regulate the alternative splicing of the TR $\beta 1$ pre-mRNA in tilapia (Mendoza et al. 2013). The other genes analyzed here are regulated in the same manner by $T_{3}$ and $T_{2}$ in this species; however, the fact that the two TR $\beta 1$ isoforms are differentially regulated by these two ligands raises the possibility that additional genes may also be differentially regulated, a suggestion that warrants further attention.

\section{Declaration of interest}

$\mathrm{P} \mathrm{N}-\mathrm{R}$ is a doctoral student from Programa de Doctorado en Ciencias Biomédicas, Universidad Nacional Autónoma de México (UNAM), and received fellowship 216637 from CONACYT.

\section{Funding}

This study was supported by grants from PAPIIT 208511 and CONACYT 166357.

\section{Acknowledgements}

The authors acknowledge the technical support of Patricia Villalobos and thank Dorothy Pless for critically reviewing the manuscript as well as Leonor Casanova and Lourdes Lara.

\section{References}

De Jesus EG, Toledo JD \& Simpas MS 1998 Thyroid hormones promote early metamorphosis in grouper (Epinephelus coioides) larvae. General and Comparative Endocrinology 112 10-16. (doi:10.1006/gcen.1998. 7103)

Galay-Burgos M, Power DM, Llewellyn L \& Sweeney GE 2008 Thyroid hormone receptor expression during metamorphosis of Atlantic halibut (Hippoglossus hippoglossus). Molecular and Cellular Endocrinology 281 56-63. (doi:10.1016/j.mce.2007.10.009)

García-G C, Jeziorski MC, Valverde-R C \& Orozco A 2004 Effects of iodothyronines on the hepatic outer-ring deiodinating pathway in killifish. General and Comparative Endocrinology 135 201-209. (doi:10. 1016/j.ygcen.2003.09.010)

García-G C, López-Bojorquez L, Nuñez J, Valverde-R C \& Orozco A 2007 3,5 Diiodothyronine $\left(3,5-\mathrm{T}_{2}\right)$ in vivo maintains euthyroidal hepatic expression of type 2 iodothyronine deiodinase and growth hormone in the killifish. American Journal of Physiology. Regulatory, Integrative and Comparative Physiology 293 877-883. (doi:10.1152/ajpregu. 00101.2007)

Goglia F 2005 Biological effects of 3,5-diiodothyronine $\left(\mathrm{T}_{2}\right)$. Biochemistry (Moscow) 70 164-172. (doi:10.1007/s10541-005-0097-0)

Lam TJ 1980 Thyroxine enhances larval development and survival in Sarotherodon (Tilapia) Mossambicus Ruppell. Aquaculture 21 287-291. (doi:10.1016/0044-8486(80)90138-6)

Lam TJ \& Sharma R 1985 Effects of the salinity and thyroxine on growth and development in the carp, Cyprinus carpio. Aquaculture 44 201-212. (doi:10.1016/0044-8486(85)90244-3)
Lam SH, Sin YM, Gong Z \& Lam TJ 2005 Effects of thyroid hormone on the development of immune system in zebrafish. General and Comparative Endocrinology 142 325-335. (doi:10.1016/j.ygcen.2005. 02.004)

Little AG, Kunisue T, Kannan K \& Seebacher F 2013 Thyroid hormone actions are temperature-specific and regulate thermal acclimation in zebrafish (Danio rerio). BMC Biology 26 11-26. (doi:10.1186/1741-700711-26)

Manchado M, Infante C, Rebordinos L \& Cañavate JP 2009 Molecular characterization, gene expression and transcriptional regulation of thyroid hormone receptors in Senegalese sole. General and Comparative Endocrinology 160 139-147. (doi:10.1016/j.ygcen.2008.11.001)

Marchand O, Duffraisse M, Triqueneaux G, Safi R \& Laudet V 2004 Molecular cloning and developmental expression patterns of thyroid hormone receptors and $\mathrm{T}_{3}$ target genes in the turbot (Scophthalmus maximus) during post-embryonic development. General and Comparative Endocrinology 135 345-357. (doi:10.1016/j.ygcen.2003. 10.012)

Mendoza CA, Navarrete-Ramírez P, Hernández-Puga G, Villalobos P, Holzer G, Laudet V, Renaud JP \& Orozco A 2013 3,5- $\mathrm{T}_{2}$ is an alternative ligand for the thyroid hormone receptor $\beta 1$. Endocrinology 158 2948-2958. (doi:10.1210/en.2013-1030)

Nacario JF 1983 The effect of thyroxine on the larvae and fry of Sarotherodon niloticus (Tilapia nilotica). Aquaculture 34 73-83. (doi:10.1016/00448486(83)90292-2)

Navarrete-Ramírez P, Orozco A, Valverde-R C, Olvera A, Toledo-Cuevas EM, Ross LG \& Martínez-Palacios CA 2011 Effects of thyroxine administration on the growth and survival of pike silverside (Chirostoma estor) juveniles. Aquaculture Research 42 808-814. (doi:10.1111/j.13652109.2011.02834.x)

Opitz R, Lutz I, Nguyen NH, Scanlan TS \& Kloas W 2006 Analysis of thyroid hormone receptor $\beta A$ mRNA expression in Xenopus laevis tadpoles as a means to detect agonism and antagonism of thyroid hormone action. Toxicology and Applied Pharmacology 212 1-13. (doi:10.1016/j.taap. 2005.06.014)

Orozco A, Ruiz JA \& Valverde-R C 1992 The importance of employing serum free of thyronines in radioimmunoassays to assess circulating thyroid hormones in rainbow trout. Boletín de Estudios Médicos y Biológicos 40 41-47.

Power DM, Llewellyn L, Faustino M, Nowell MA, Björnsson BT, Einarsdottir IE, Canario AV \& Sweeney GE 2001 Thyroid hormones in growth and development in fish. Comparative Biochemistry and Physiology. Toxicology \& Pharmacology 130 447-459. (doi:10.1016/ S1532-0456(01)00271-X)

Reddy PK \& Lam TJ 1992 Role of thyroid hormones in tilapia larvae (Oreochromis mossambicus). Effects of the hormones and an antithyroid drug on yolk absorption, growth and development. Fish Physiology and Biochemistry 9 473-485. (doi:10.1007/BF02274228)

Sachs LM, Damjanovski S, Jones PL, Li Q, Amano T, Ueda S, Shi YB \& Ishizuya-Oka A 2000 Dual function of thyroid hormone receptors during Xenopus development. Comparative Biochemistry and Physiology. Part B, Biochemistry \& Molecular Biology 126 199-211. (doi:10.1016/ S0305-0491(00)00198-X)

Sadow PM, Chassande O, Koo EK, Gauthier K, Samarut J, Xu J, O’Malley BW \& Weiss RE 2003 Regulation of expression of thyroid hormone receptor isoforms and coactivators in liver and heart by thyroid hormone. Molecular and Cellular Endocrinology 203 65-75. (doi:10.1016/S03037207(03)00122-9)

Schapira M, Raaka BM, Das S, Fan L, Totrov M, Zhou Z, Wilson SR, Abagyan R \& Samuels HH 2003 Discovery of diverse thyroid hormone receptor antagonists by high-throughput docking. PNAS $\mathbf{1 0 0}$ 7354-7359. (doi:10.1073/pnas.1131854100)

Schmid AC, Lutz I, Kloas W \& Reinecke M 2003 Thyroid hormone stimulates hepatic IGF-I mRNA expression in a bony fish, the tilapia Oreochromis mossambicus, in vitro and in vivo. General and Comparative Endocrinology 130 129-134. (doi:10.1016/S0016-6480(02)00577-4) 
Shah V, Nguyen P, Nguyen NH, Togashi M, Scanlan TS, Baxter JD \& Webb P 2008 Complex actions of thyroid hormone receptor antagonist NH-3 on gene promoters in different cell lines. Molecular and Cellular Endocrinology 296 69-77. (doi:10.1016/j.mce.2008.09.016)

Tata JR 2000 Autoinduction of nuclear hormone receptors during metamorphosis and its significance. Insect Biochemistry and Molecular Biology 30 645-651. (doi:10.1016/S0965-1748(00) 00035-7)
Tata JR 2002 Signalling through nuclear receptors. Nature Reviews. Molecular Cell Biology 3 702-710. (doi:10.1038/nrm914)

Timmer DC, Bakker O \& Wiersinga WM 2003 Triiodothyronine affects the alternative splicing of thyroid hormone receptor $\alpha$ mRNA. Journal of Endocrinology 179 217-225. (doi:10.1677/joe.0.1790217)

Yamano K \& Miwa S 1998 Differential gene expression of thyroid hormone receptor $\alpha$ and $\beta$ in fish development. General and Comparative Endocrinology 109 75-85. (doi:10.1006/gcen.1997.7011)

Received in final form 6 September 2013

Accepted 12 September 2013

Accepted Preprint published online 12 September 2013
Published by Bioscientifica Ltd. 